\title{
Weathering and erosional processes within the landslide deposit of Jarlang (Ganesh Himal), central Nepal
}

\author{
C. F. Uhlir and J.M. Schramm \\ Department of Geology and Palaeontology, University of Salzburg, \\ Hellbrunnerstrasse 34/III, 5020 Salzburg, Austria
}

\begin{abstract}
Within the southern flanks of the Ganesh Himal in central Nepal, an area of complex landslides lies in the Jarlang area, situated at the southeastern slope of the Ankhu Khola valley. Slow rotational rockslide in deeply weathered micaceous quartzites interlayering with mica schists have destabilized the head scarp composed of augen gneiss. It caused rockslides from the main scarp generating big spread-out landslides. The landslides of Jarlang generated a stratified deposit $\left(>10^{6} \mathrm{~m}^{3}\right)$ of matrix-poor breccias with thin fine grained shear horizons.

The initial event for the biggest gully system in central Nepal was a gravitational slump owing to nineday heavy rainfall in 1954 . The recent processes within these colluvial deposits are torrential gully erosion accompanied by successive rotational and translational slides along the gully margins. The high activity within the Jarlang gully system can be explained by reactivation of the old Jarlang landslide's shear horizons. The slide grew from an original width of $300 \mathrm{~m}$ to $1.2 \mathrm{~km}$ at present, covering an area of $2.68 \mathrm{~km}^{2}$. The total volumetric loss by 1996 is $1.46 \times 10^{8} \mathrm{~m}^{3}$.

The triggering factor for rock slides and rock falls generating big spread out landslides and debris slides and slope undercutting is seismic events due to extremely high uplift of the Himalayan Orogeny. The strong influence of human activities on slope stability and mass wasting as proposed in the Himalayan Environmental Degradation Theory can not be validated.
\end{abstract}

\section{GEOGRAPHIC FEATURES AND CLIMATE}

The study area lies at the southern flank of the Ganesh Himal's main ridge $\left(28^{\circ} \mathrm{N}, 85^{\circ} \mathrm{E}\right)$ in the Dhading district (central Nepal) about $50 \mathrm{~km}$. It is divided by the $4000 \mathrm{~m}$ high, N-S running, rocky and sharp-edged ridges Khurpu and Marsyung Danda and very deep gorges. The study area is situated in the mid stage between 1400-3500 m (Thouret, 1981), which is most severely hit by the summer monsoon impact, with $3000-4000 \mathrm{~mm}$ of precipitation within three and a half months. Nearly all the year, even during the winter monsoon, precipitation is very low, only the summer monsoon and exceptional tropical cyclones bring heavy rainfall (Thompson and Devkota, 1989). The mid stage is subdivided into the cultivated lower mid stage $(1400-2500 \mathrm{~m})$ and the wooded higher mid stage $(2400-3500 \mathrm{~m})$. The lower subtropical stage, elevation between 500 and $1500 \mathrm{~m}$, with red colored fersiallitic soil, is not developed in the study area (Thouret, 1981).

\section{GEOLOGIC SETTING}

The lithology is dominated by Palaeozoic mica quartzites of the Lower Midland Formation of Le Fort (1975) corresponding to the Kuncha Formation of Stöcklin (1980), weakened by intercalations of mica schists with discontinuous levels of thick and compact ortho gneiss (Ulleri augen gneiss) and small amounts of amphibolite (Fig. 1). The metamorphic grade of the rocks is green schist facies (Pecher, 1977).

The tectonic structures were formed by successive deformation stages (Pecher, 1977). In the study area, the most important ones are: 


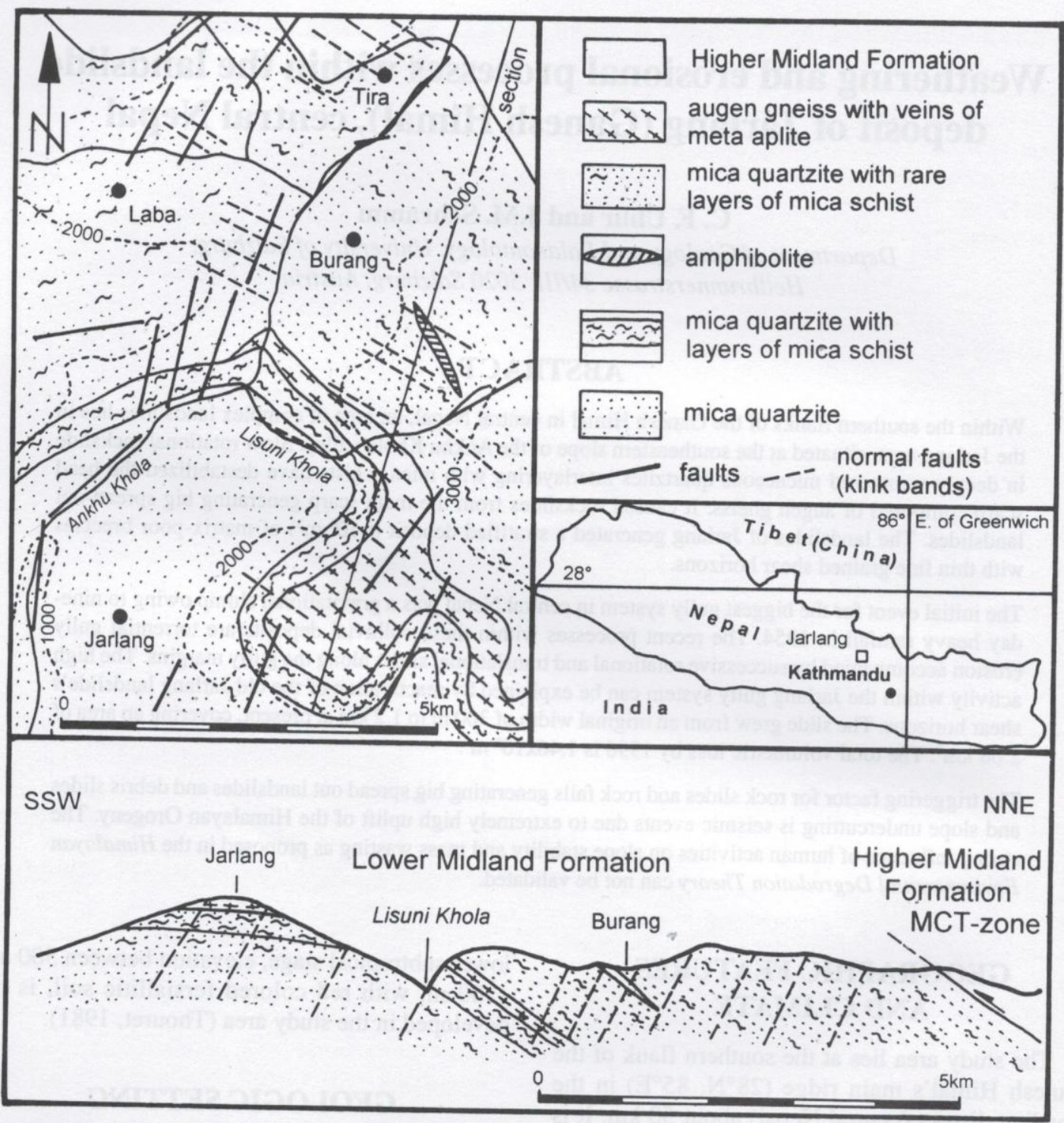

Fig. 1: Geologic sketch-map of the study area.

- Schistosity $\mathrm{S}_{1}$ (dipping $10-30^{\circ}$ toward NW or $\mathrm{NE}$ ), which is roughly parallel to the primary bedding $\mathrm{S}_{0}$,

- Simple folds, with b-axis dipping parallel to $S_{1}$,

- Schistosity $\mathrm{S}_{2}$, generally dipping $10-15^{\circ}$ steeper than $\mathrm{S}_{1}$,

- Schistosity $S_{3}$, general dipping $45-55^{\circ}$ toward $\mathrm{NE}$, morphologically important,

- Series of kink bands, described as normal faults (Bogacz and Krokowski, 1986) with a $60-70^{\circ}$ dip to SW-SSW, and
Series of faults which strike from SSW to NNE and SW to NE. Within the Ankhu Khola valley these faults are connected with the Thaple shear fault system of Valdiya (1976).

\section{UPLIFT AND PRECIPITATION - CAUSES OF MASS MOVEMENTS}

High rates of recent uplift and a high annual precipitation force intensive fluvial dissection of the 
Ganesh Himal ranges. They are the main causes of the instability of slopes, resulting in a wide range of mass movements.

The uplift of the Himalaya, documented in the sediments of the Bengal fan, was rather a succession of high uplift rates with very low rates in between (Amato and Taira, 1992). High rates of recent uplift are indicated by the abrupt increase in sediment supply of the Bengal fan $0.8 \mathrm{Ma}$ ago (Mugnier et al., 1996). Active tectonic shortening of around 15 $\mathrm{mm} / \mathrm{yr}$ (Powers and Lille, 1996; Yeats, 1996) and erosionally driven isostatic recovery (Burbank, 1992) are, both singly and in conjunction, used as an explanation for this increase of sediment supply. Both effects are used to explain the current geodetic uplift rates of $17-18 \mathrm{~mm} / \mathrm{yr}$ in central Nepal (according to discussions with R. S. Yeats).

The monsoon impact as the main factor for erosional processes and sediment transportation in the Ganesh Himal area is well documented by Thouret (1981) and explained as a phenomenon discontinuous in time and space. The monsoon, with a duration of three and a half months, has its maximum impact of up to $4000 \mathrm{~mm}$ between the thermic limits of $1400-1600 \mathrm{~m}$ and $2700-3000 \mathrm{~m}$. The secondary maximum impact (up to $3500 \mathrm{~mm}$ ) is between 3000 and $4000 \mathrm{~m}$. Outside these horizons the climate is relatively dry. There is a high correlation between the lower maximum impact and the area most severely affected by catastrophic slope dynamics. Thunderstorms outside the monsoon period, especially during spring, have no major effect on unstable dynamic areas (Thouret, 1981). On the contrary, Carson (1985) assumes that catastrophic rainstorms with a long recurrence interval are the major triggering mechanism for large-scale slope failures, like the 1954 event in the Ganesh Himal area (Uhlir and Schramm, 1996a).

\section{WEATHERING CHARACTERISTICS OF THE COLLUVIAL DEPOSITS}

The cultivated and cleared mid stage (1600 - 2700 $\mathrm{m}$ ) is characterized by brown-ochre soils above 2000 $\mathrm{m}$, brown soils between 1700 and $2000 \mathrm{~m}$ and brown fersiallitic soils below $1700 \mathrm{~m}$ (Thouret, 1981). The omnipresent and mostly very thick colluvial deposits are highly affected by physical weathering.
Subsurface chemical weathering generating mixed layer smectites occurs below $2000 \mathrm{~m}$. The colluvial deposits of the old Jarlang landslide (consisting of heavily shattered and pulverized Ulleri augen gneiss) are rarely affected by subsurface chemical weathering and free of mixed layer smectites. The shear horizons in the center of the gully $(1800 \mathrm{~m})$ are highly altered, and show higher amounts of illite and no chlorite. The heavily altered debris of the Jarlang gully contain vermiculite, illite and kaolinite.

\section{MORPHOLOGY VERSUS GEOLOGY}

The morphology and drainage system in the Lower Midland Formation clearly manifest the main tectonic structure of the Khuncha-Gorkha anticline. The N-S and NNE-SSW directed rivers follow fault zones. The steep slopes with a low order trend surface show triangularly shaped scarps, following the normal faults (kink bands) and the schistosity $\mathrm{S}_{3}$ of the anticline (Uhlir and Schramm, 1996b).

\section{The Strong Dissymetry Between the North and South Facing Slopes}

On the tributaries' north facing slopes of the upper Ankhu Khola and along the Bemdang Khola, Chilime Khola, Langtang Khola and Trisuli Khola, the slope is generally less than $30^{\circ}$ and is parallel to the foliation of the anticline. South facing slopes of this region generally have slope angles between $40^{\circ}$ and $60^{\circ}$. The less steeply north facing slopes are highly affected by mass movements and covered by thick colluvial deposits of rockslides generating a debris slides and debris flows. Wedge shaped, slow translational rockslides with temporary ponds and tiny lakes on their backside are frequent.

The south facing slopes show low activity of small single rock falls, rock topples and rock slides generating debris fans, debris slides and debris flows. The main reason for this non-symmetric slope evolution is the alteration of mica quartzites and mica schists of the north dipping Kuncha Formation. The mica schists are the sliding planes on the north facing slopes, with typical development of very slow successive and multiple rockslides and slow single or multiple rockslides generating debris slides or debris flows. 
Moderate slope angles in other directions, like in the mid Ankhu Khola region indicate colluvium of up to $100 \mathrm{~m}$ thickness.

\section{The strong Dissymetry between the Slope's Front and Back Side}

The front side of the slope $\left(<45^{\circ}\right)$ is generally more stable than the back side. Only a few mass movements like small debris slides, rock topples and rockslides affect the slope's front side due to gravity and stream undercutting. One of the slow multiple rockslides, which has been active for 20 years is observed beneath the village of Labdung. A part of the village has already been lost.

The back side of the north facing slopes, with an inclination of $35-45^{\circ}$, generally show a typical morphology of slow rockslides and big steps (up to $40 \mathrm{~m}$ wide) resulting from multiple rockslides. Back side ditches also result in slow single rockslides. Slow disintegration by weathering of the shifted rock wedges causes composite rock and debris slides generating debris flows as one near the village of Khading.

The activity of the debris depends on the rate of disintegration and varies from shallow activities like debris creep and gullying to deep seated, fast debris slides generating debris flows. The area between the back and front side is covered by thick and heavy disintegrated debris or compact, wedge shaped rockslides with temporary ponds or tiny lakes in their backside ditch. The activity of those meta-stable slide deposits can be very low over decades.

\section{TYPES OF MASS MOVEMENTS}

\section{Types of Mass Movements within the Solid Bedrock}

The size of mass movements within bedrock depends on the cohesion of the rock, the order of the trend surface and the grade of weathering. Areas of rocks with high cohesion like gneiss and quartzite and a low order of the trend surface generally show low activity over long periods, interrupted by big and very hazardous events (Heim, 1932). Heavy earthquakes with a renewal time of 250-500 years (Bilham et al., 1995) are expected as a possible triggering factor for those big mass movements. The main factor is selftriggering in overcritical conditions (Uhlir, 1993). The influence of precipitation decreases with the size of the mass movement. Types of mass movements and their characteristics are presented in Table 1. Table 2 shows the structures and fracture behaviour of parent rocks in the Jarlang landslide. Clay mineralogy and engineering properties of the Jarlang landslide is given in Table 3.

Table 1: Types of mass movements and their characteristics.

\begin{tabular}{|c|c|c|c|c|}
\hline Type of mass movements & Velocity & Assisting factors & External Trigger & Activity \\
\hline $\begin{array}{l}\text { spread out landslides generated } \\
\text { by rock slides and falls }\end{array}$ & $\begin{array}{l}\text { extremely rapid } \\
\text { (up to } 90 \mathrm{~m} / \mathrm{s} \text { ) }\end{array}$ & $\begin{array}{l}\text { schistosity, jointing, } \\
\text { faults }\end{array}$ & $\begin{array}{l}\text { seismic events, self } \\
\text { triggering }\end{array}$ & $\begin{array}{l}\text { inactive - } \\
\text { episodic }\end{array}$ \\
\hline $\begin{array}{l}\text { rock slides and rock falls } \\
\text { generating debris flow }\end{array}$ & $\begin{array}{l}\text { extremely rapid } \\
\text { (up to } 30 \mathrm{~m} / \mathrm{s} \text { ) }\end{array}$ & $\begin{array}{l}\text { schistosity, jointing, } \\
\text { faults }\end{array}$ & $\begin{array}{l}\text { seismic events, self triggering, } \\
\text { monsoonal precipitation }\end{array}$ & inactive - \\
\hline $\begin{array}{l}\text { rotational rock slides } \\
\text { (successive) }\end{array}$ & $\begin{array}{l}\text { extremely-very } \\
\text { slow }\end{array}$ & weathering & water saturation & $\begin{array}{l}\text { episodic - } \\
\text { permanent }\end{array}$ \\
\hline rock fall & $\begin{array}{l}\text { extremely rapid } \\
\text { (up to } 15 \mathrm{~m} / \mathrm{s} \text { ) }\end{array}$ & $\begin{array}{l}\text { schistosity, jointing } \\
\text { slope angle }\end{array}$ & $\begin{array}{l}\text { wind, precipitation, seismic } \\
\text { events, self triggering }\end{array}$ & $\begin{array}{l}\text { episodic - } \\
\text { permanent }\end{array}$ \\
\hline $\begin{array}{l}\text { successive rotational } \\
\text { (wedge shaped) debris slides }\end{array}$ & $\begin{array}{l}\text { slow - moderate } \\
(1.5 \mathrm{~m} / \mathrm{a} \text { to } \\
1.5 \mathrm{~m} / \mathrm{month}) \\
\end{array}$ & gullying & $\begin{array}{l}\text { water saturation slope } \\
\text { undercutting }\end{array}$ & episodic \\
\hline $\begin{array}{l}\text { successive translational } \\
\text { debris slides }\end{array}$ & $\begin{array}{l}\text { slow - moderate } \\
(1.5 \mathrm{~m} / \mathrm{a} \text { to } \\
1.5 \mathrm{~m} / \mathrm{month})\end{array}$ & $\begin{array}{l}\text { preexiting flat failure } \\
\text { surface of fine grained } \\
\text { nature, gullying }\end{array}$ & water saturation & episodic \\
\hline debris avalanches & $\begin{array}{l}\text { very rapid } \\
\text { (up to } 10 \mathrm{~m} / \mathrm{s} \text { ) }\end{array}$ & $\begin{array}{l}\text { debris accumulation } \\
\text { within the gully }\end{array}$ & water saturation & episodic \\
\hline gullying & & weathering & monsoonal precipitation & permanent \\
\hline debris creep & slow to very slow & $\begin{array}{l}\text { slope undercutting } \\
\text { debris accumulation }\end{array}$ & water saturation & $\begin{array}{l}\text { episodic / } \\
\text { permanent }\end{array}$ \\
\hline
\end{tabular}


Table 2: Structures and fracture behaviour of parent rocks in Jarlang landslide.

\begin{tabular}{|l|l|l|l|}
\hline No. & \multicolumn{1}{|c|}{ Parent rock } & \multicolumn{1}{c|}{$\begin{array}{c}\text { Behavior of } \\
\text { fracturing }\end{array}$} & \multicolumn{1}{c|}{ Structure } \\
\hline U31J & muscovite biotite quartzite & brittle and splintery & fine grained, fine layered \\
\hline U16J & muscovite biotite quartzite & brittle and splintery & $\begin{array}{l}\text { fine grained, layered, with mica rich } \\
\text { layers }\end{array}$ \\
\hline U2J & muscovite biotite quartzite & blocky platy & fine grained, compact thick layered \\
\hline U29J & muscovite biotite quartzite & platy and brittle & $\begin{array}{l}\text { gray fine grained, compact, with mica } \\
\text { rich layers }\end{array}$ \\
\hline U28J & muscovite biotite quartzite & brittle and splintery & $\begin{array}{l}\text { fine grained, thin layered, with mica } \\
\text { rich layers }\end{array}$ \\
\hline U11J & ortho gneiss & blocky and splintery & $\begin{array}{l}\text { medium grained, massive granitic } \\
\text { structure }\end{array}$ \\
\hline U10J & meta aplite & blocky and splintery & $\begin{array}{l}\text { medium grained, massive granitic } \\
\text { structure }\end{array}$ \\
\hline
\end{tabular}

Table 3: Clay mineralogy and engineering properties of Jarlang landslide.

\begin{tabular}{|l|l|l|l|l|l|}
\hline No. & Rock slide debris & Clay minerals & $\begin{array}{l}\text { Permea- } \\
\text { bility }\end{array}$ & U=d60/d10 & $\begin{array}{l}\text { C=(d30 })^{2} \\
\text { /d10.d60 }\end{array}$ \\
\hline J6 & Cl,-cg,-cs,-ms,-fs & $\begin{array}{l}\text { illite, chlorite, kaolinite, mixed layer } \\
\text { illite-chlorite, albite, microcline }\end{array}$ & $1.1 \mathrm{E}-7$ & 20.65 & 0.38 \\
\hline J8 & $\mathrm{Cl},-\mathrm{cg},-\mathrm{cs},-\mathrm{ms},-\mathrm{fs}$ & $\begin{array}{l}\text { illite, chlorite, kaolinite, mixed layer } \\
\text { illite-chlorite, albite, microcline }\end{array}$ & $1.3 \mathrm{E}-7$ & 29.13 & 0.24 \\
\hline J9 & $\mathrm{Cl},-\mathrm{cg},-\mathrm{cs},-\mathrm{ms},-\mathrm{fs}$ & $\begin{array}{l}\text { illite, chlorite, kaolinite, mixed layer } \\
\text { illite-chlorite, albite, microcline }\end{array}$ & $1.6 \mathrm{E}-7$ & 39.67 & 0.13 \\
\hline J13 & $\mathrm{Cl},-\mathrm{cg},-\mathrm{cs},-\mathrm{ms},-\mathrm{fs}$ & illite, kaolinite, albite & $1.9 \mathrm{E}-7$ & 22.11 & 0.19 \\
\hline J14 & $\mathrm{Cl}, \mathrm{cg},-\mathrm{cs},-\mathrm{ms},-\mathrm{fs}$ & illite, kaolinite, albite & $1.7 \mathrm{E}-7$ & 8.63 & 0.56 \\
\hline J7 & $\mathrm{C},+\mathrm{cl}, \mathrm{cg}, \mathrm{ms},-\mathrm{mg},-\mathrm{cs},-\mathrm{fs}$ & $\begin{array}{l}\text { illite, chlorite, kaolinite, mixed layer } \\
\text { illite-chlorite, albite, microcline }\end{array}$ & $6.1 \mathrm{E}-7$ & 130.44 & 0.13 \\
\hline J11 & $\mathrm{C},+\mathrm{cl}, \mathrm{cg}, \mathrm{ms},-\mathrm{mg},-\mathrm{cs},-\mathrm{fs}$ & $\begin{array}{l}\text { illite, chlorite, kaolinite, mixed layer } \\
\text { illite-chlorite, albite, microcline }\end{array}$ & $1.1 \mathrm{E}-7$ & 116.29 & 0.34 \\
\hline J4 & $\mathrm{G}, \mathrm{cs},-\mathrm{ms},-\mathrm{fs},-\mathrm{cl}$ & $\begin{array}{l}\text { illite, chlorite, kaolinite, mixed layer } \\
\text { illite-chlorite, albite, microcline }\end{array}$ & $2.2 \mathrm{E}-7$ & 82.92 & 2.30 \\
\hline J15 & G,cs,-ms,-fs & $\begin{array}{l}\text { illite, kaolinite, vermiculite, mixed layer } \\
\text { illite-chlorite }\end{array}$ & $1.8 \mathrm{E}-4$ & - & - \\
\hline J17 & G+S,-cl & $\begin{array}{l}\text { illite, kaolinite, vermiculite, mixed layer } \\
\text { illite-chlorite }\end{array}$ & $3.3 \mathrm{E}-5$ & 51.48 & 1.54 \\
\hline J2 & G,-cs,-ms,-cl & $\begin{array}{l}\text { illite, kaolinite, vermiculite, mixed layer } \\
\text { illite-chlorite }\end{array}$ & $4.7 \mathrm{E}-4$ & - & - \\
\hline J3 & G,-cs,-ms,-fs,-cl & $\begin{array}{l}\text { illite, kaolinite, vermiculite, mixed layer } \\
\text { illite-chlorite }\end{array}$ & $4.2 \mathrm{E}-5$ & 54.41 & 1.53 \\
\hline
\end{tabular}

The following mass movements within the bedrock are observed:

- Large rapid rockslides and rockfalls $\left(>10^{6} \mathrm{~m}^{3}\right)$ generating debris flow, so called rapid spread out landslides, which move en bloc and spread out along shear horizons along slope angles less than $30^{\circ}$. The facies of their colluvial deposits are generally stratified; damming of rivers including catastrophic outbursts can happen.
- Small rapid rockslides and rockfalls $\left(<10^{6} \mathrm{~m}^{3}\right)$ generating debris flow and debris fans, generation of debris flows only along slope angles more than $30^{\circ}$. The colluvial deposits are uniform and non-stratified. No damming was observed.

- Slow translational rockslides along the foliation. These rockslides frequently have temporary ponds or tiny lakes in the back side ditch. 


\section{F. Uhlir and J.M. Schramm}

Depending on the rock type the slow-moving rock slides disintegrate by weathering and high water saturation generating debris slides.

- Minor rockfalls generating very stable debris fans.

\section{Types of Mass Movements within the Colluvial Deposits}

The activity within the colluvium depends on the nature and grade of weathering, which in turn depends on the altitude and type of material. Coarse grained uniform deposits of small rapid rockslides and rockfalls and talus rockfalls are usually quite stable. The deposits of large rapid rockslides and rockfalls are stratified, show a wide range of disintegration and are most severely affected by gullying. The basal sliding planes of the rapid landslides consist of fine grained rock fragments in silty, clayey matrix, and may be rejuvenated during the heavy rainfall. Gullying within big landslide deposits is accompanied by rotational slides along the side scarps. These sliding areas reach a dimension of a few square kilometers within a few years, and are the major hazard along the Ankhu Khola.

The following mass movements within the colluvial deposits are observed:

- Rotational (partially successive) debris slumps within heavily weathered debris,

- Translational (partially successive) debris slides along preexisting sliding planes: old soils and shear horizons of long runout landslides,

- Gullying, small scale along steep $\left(>30^{\circ}\right)$, mostly deforested slopes, up to giant scale within thick colluvial deposits $\left(<30^{\circ}\right)$,

- Surface erosion (debris fall and debris creep), and

- Debris avalanches within giant gully systems and fine grained colluvial deposits.

\section{Human Activities, Mass Movements and Soil Erosion}

The following human activities have an impact on slope stability:

Building of terraces in the uplands causes loss of equilibrium of the soil (debris) due to loss of cohesion (Thouret, 1981).
Extensive deforestation around villages for farmland, fuel wood and construction material in the lower mid stage, and slash and burn within the higher mid stage for grazing land cause surface erosion and shallow debris slides. Activity is relatively low compared to naturally caused slides (Thouret, 1981).

\section{WEATHERING AND EROSION WITHIN THE LANDSLIDE DEPOSIT OF JARLANG}

A complex landslide area is located within the Jarlang village area at the Ankhu Khola's south-eastern slope, within the lower mid stage - with a monsoonal maximum of $4000 \mathrm{~mm}$ precipitation. This area exemplifies a wide range of slow and extremely rapid mass movements within bedrock, which generated an up to $80 \mathrm{~m}$ thick colluvial cover (Fig. 2).

The inner structure of the colluvial deposits depends on their generation:

- Relatively uniform due to successions of rapid rockslides $\left(<10^{6} \mathrm{~m}^{3}\right)$,

- Stratified within the deposit of big, spread out, landslides $\left(>10^{6} \mathrm{~m}^{3}\right)$, and

- Highly disintegrated and weathered deposits from slow, deep seated rockslides.

The main triggering factors for rock slides and rock falls are (Fig. 3):

- Main foliation, dipping roughly parallel to the slope direction. A zone of normal faults is cutting the scarps into $20-50 \mathrm{~m}$ wide sections,

- Thin layers of interstratifying mica schists, weakening compact mica quartzites,

- A $120 \mathrm{~m}$ thick layer of compact augen gneiss lying on top of a succession of mica quartzite and mica schist.

The main triggering factors for slides within the thick colluvium are:

- Successions of thin shear horizons within highly differentiated landslide debris and soil horizons of varying age,

- A high grade of disintegration within slow translational rockslides,

- Quick subsurface weathering driven by the high monsoonal precipitation, which is also forcing torrential gullying and surface erosion, and 
Weathering and erosional processes within the landslide deposit of Jarlang (Ganesh Himal)

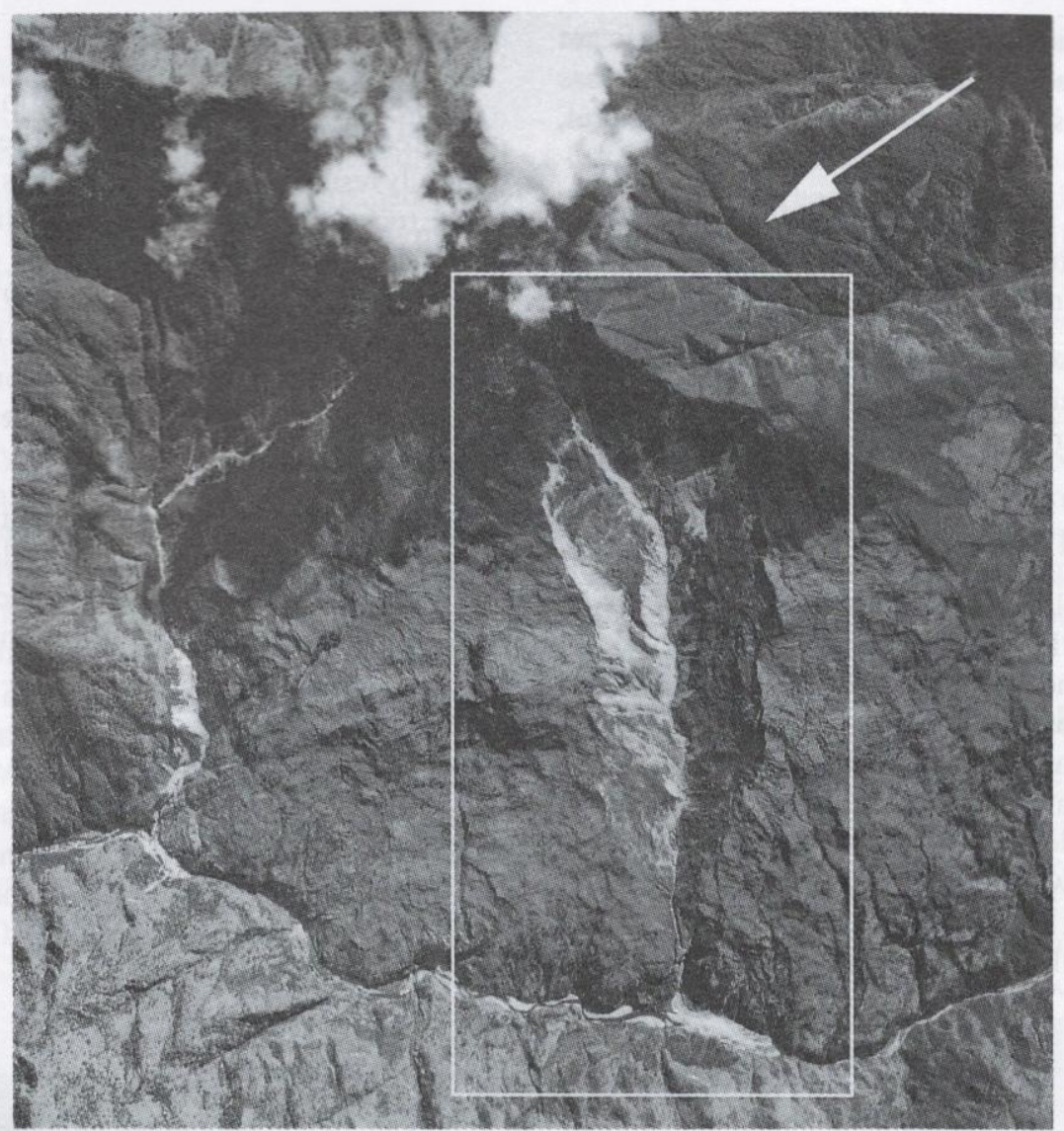

Figure 2: Aerial photograph (No. 60-11, 1993) of the gully Jarlang, scale $\sim 1: 40.000, \neg=$ area mapped in detail, $\uparrow=$ North

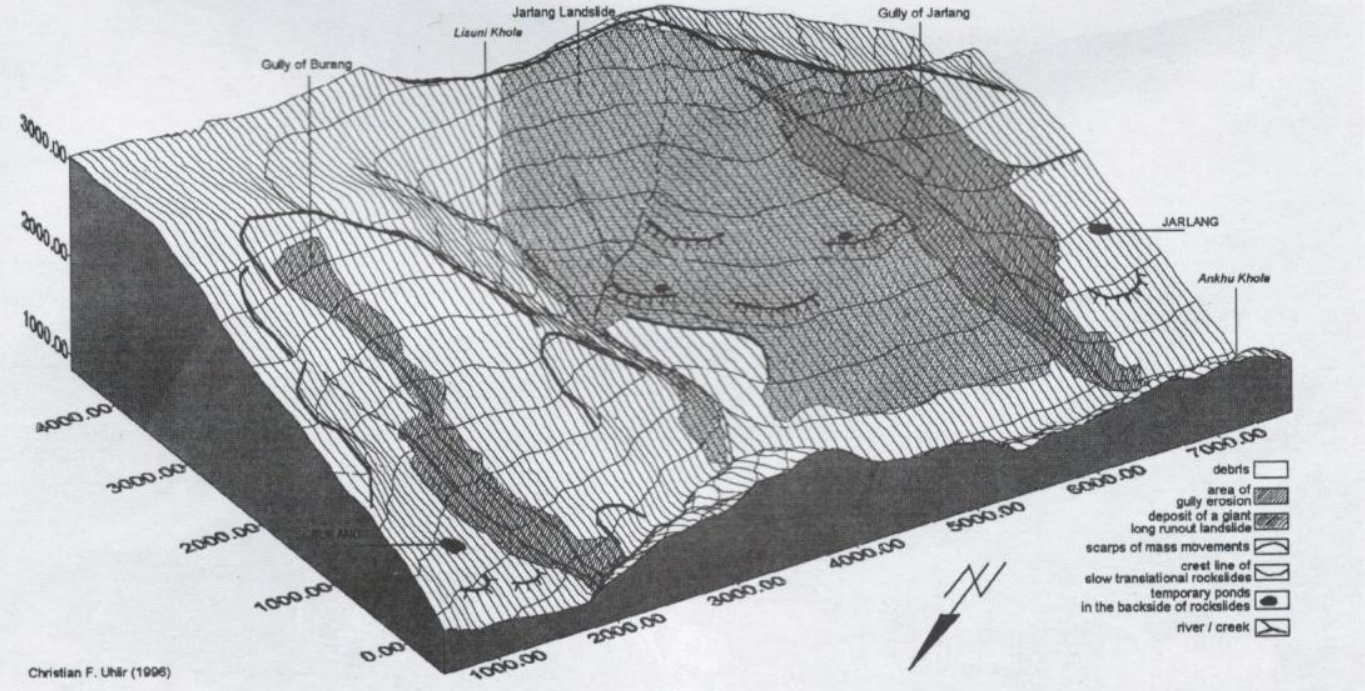

Figure 3: Surface plot of the Jarlang landslide area 


\section{F. Uhlir and J.M. Schramm}

- Deforestation does not seem to be a significant assisting factor in medium and large scale mass movements (Marston and Miller, 1987; Thouret, 1981)

The main triggering factors for gravitational slides within the bedrock and the colluvium are of a cyclic nature, namely:

- High monsoonal precipitation (annually)

- Catastrophic rainstorms (every 30 to 60 years)

- Heavy seismic activities (every 250 to 500 years)

\section{Hydrological Situation}

The hydrological situation within the colluvial deposit of Jarlang is determined by the grade of weathering and the grain size distribution of the colluvial deposits. In the case of Jarlang, several areas of permanent surface moisture and some tiny lakes are situated on the back side of slow, deepseated rockslides (Fig. 4). The surface water drainage is very good within the coarse-grained deposits of the old Jarlang landslide. No springs are documented outside the gully area except along the Lisuni Khola.

\section{Succession of Mass Movements}

First, deep seated, slow rotational rockslides occurred within the mica quartzites and schists, typically resulting in temporary ponds in the backside of the rockslide. These slides destabilized the slope's backside, causing minor rockslides $\left(<10^{6} \mathrm{~m}^{3}\right)$ and giant rockslides $\left(>10^{6} \mathrm{~m}^{3}\right)$ (Abele, 1974), also called spread-out landslides (Schaller, 1991). The Jarlang giant landslide event occurred more than 3 to 4 centuries ago (according to the state of the vegetation).

According to the villagers, about 100 years ago a subterranean emptying of a tiny lake within the backside of the slow Lakcho rockslide occurred, thus giving evidence of movement within this rockslide.

About 45 years ago, there was a small rockfall $\left(<10^{5} \mathrm{~m}^{3}\right)$, originating from the southwestern part of the Jarlang landslide's head scarp. Witnesses recall that in 1954, at the end of the summer monsoon, after 9 days of continuous heavy rainfall, a series of landslides and rockfalls occurred in the entire Ganesh Himal region. The biggest cases of gravity slides within the colluvium (with average slope angles of

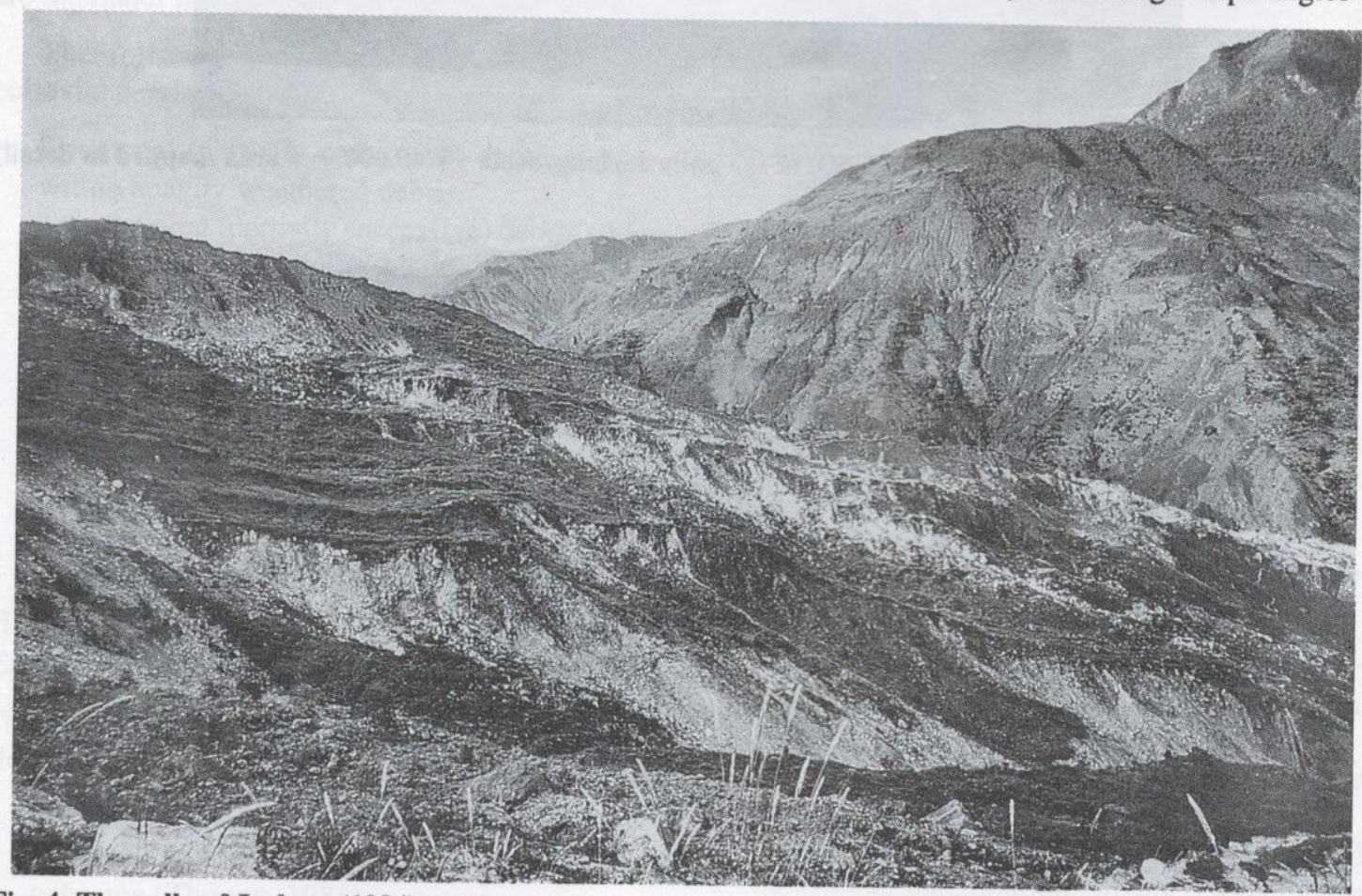

Fig. 4: The gully of Jarlang (1994) 
$25^{\circ}$ ) occurred in Jarlang within the deposits of the Jarlang landslide. Five hamlets including $1.07 \mathrm{~km}^{2}$ of farmland slid down, killing 300 people. No damming of the Ankhu Khola was reported. Since this catastrophe, the slide area have remained active as complex, successive and multiple types of landslide (Brown et al., 1992). Gullying within the slide area caused successive rotational and translational slides along the side scarps.

The gully of Jarlang was enlarged into a giant torrential gullying system, notching a new valley within 40 years (Fig. 5 and 6). The villagers of Jarlang did not protect the gully area from grazing and wood cutting. The slide grew from an original width of $300 \mathrm{~m}$ to $1.2 \mathrm{~km}$ at present, covering an area of $2.68 \mathrm{~km} 2$. The total volumetric loss 1996 is $1,46 \times 10^{8} \mathrm{~m} 3$. The suggestion of Thouret (1981) of an average annual loss of material of $2,5 \times 10^{6} \mathrm{~m}^{3}$ added to the volume of the initial event (1954) results in nearly the same figure.

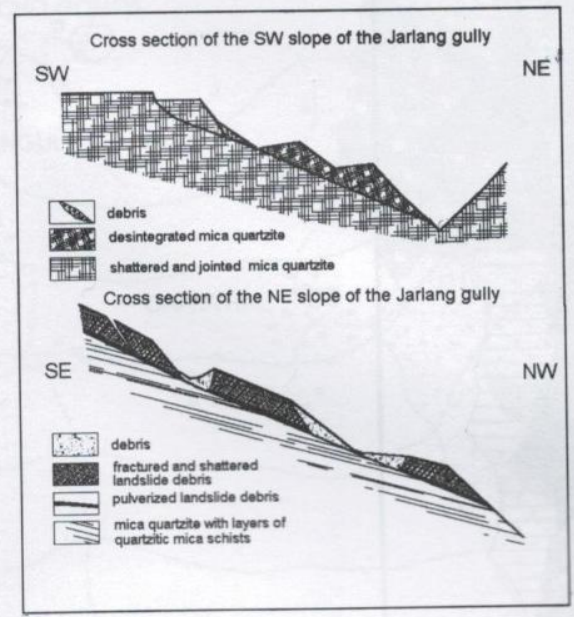

Fig. 5: Wedge shaped slides on the southwestern flank of the gully of Jarlang

The sketch-maps of the development of the Jarlang gully (Fig. 7) give an idea of the area expected to be damaged during the next 10 years. The Jarlang's colluvium is composed of a succession of heavily fractured shattered and pulverized rock (partially cataclastic), with a partial preservation of the origin rock structure. These very compact layers with a stable slope angle of up to $50^{\circ}$ are interlayered by fine-grained, pulverized shear horizons (kakirites according to Heitzmann, 1985). These shear horizons within the old Jarlang landslide deposits were highly altered by subsurface weathering and are reactivated by the gullying and result in translational slides along the central scarp and northeastern side scarps. Open cracks behind the scarp of the gully confirm the possibility of sustained growth similar to the last 40 years. In the next several years, rockslides $\left(<10^{6} \mathrm{~m}^{3}\right)$ from above the gully may also be expected.

The sketch-maps of the gully development were compiled using witness reports, the topographic map $71 \mathrm{H} 4$ of 1:63360 scale, aerial photographs from 1978 and 1992 and ground surveys during 19931994. The volumetric data was calculated using four different surface grids (average error of 10\%).

\section{THE JARLANG LANDSLIDE DEPOSIT}

The 15 to $50 \mathrm{~m}$ thick stratified deposit of the old Jarlang landslide encompasses an area of $12 \mathrm{~km}^{2}$. The volume of the landslide, is more than $2,5 \times 10^{8}$ $\mathrm{m} 3$. The maximum elevation drop is approximately $2000 \mathrm{~m}$. The head scarp follows a fault zone dipping $85^{\circ}$ to the WNW, interrupted by kink bands dipping $70^{\circ}$ to the SSW. The landslide deposit consists mainly of micro and megabreccia with basal (primary) shear horizons of a fine-grained nature. The material involved is orthogneiss (Ulleri augen gneiss) and secondary mica quartzite and schist of the Lower Midland Formation (Fig. 8).

Outcrops within the gully of Jarlang and along the Lisuni Khola river confirm the theory that big, long runout landslides travel en bloc and spread out along thin shear horizons which lubricate the movement (Schaller, 1991). The facies of the deposits varies with the relative distance from the source region and with the nature (Yarnold and Lombard, 1989) and water saturation of the Fahrbahn (Sassa, 1988 and Heim 1932). The thickness of the basal shear zones increases with the distance from the head scarp, from about 20 $\mathrm{cm}$ to $1,5 \mathrm{~m}$ ( $5 \mathrm{~m}$ at the Lisuni Khola). Near the head scarp a succession of three thin shear horizons, embedded in heavily shattered rock, demonstrate an uneven sliding plane. Small obstacles will be egalized by the generation of new shear horizons within the sliding mass. The backside trough of bigger obstacles is filled by successive overridings of the sliding mass (Fig. 9). 


\section{F. Uhlir and J.M. Schramm}

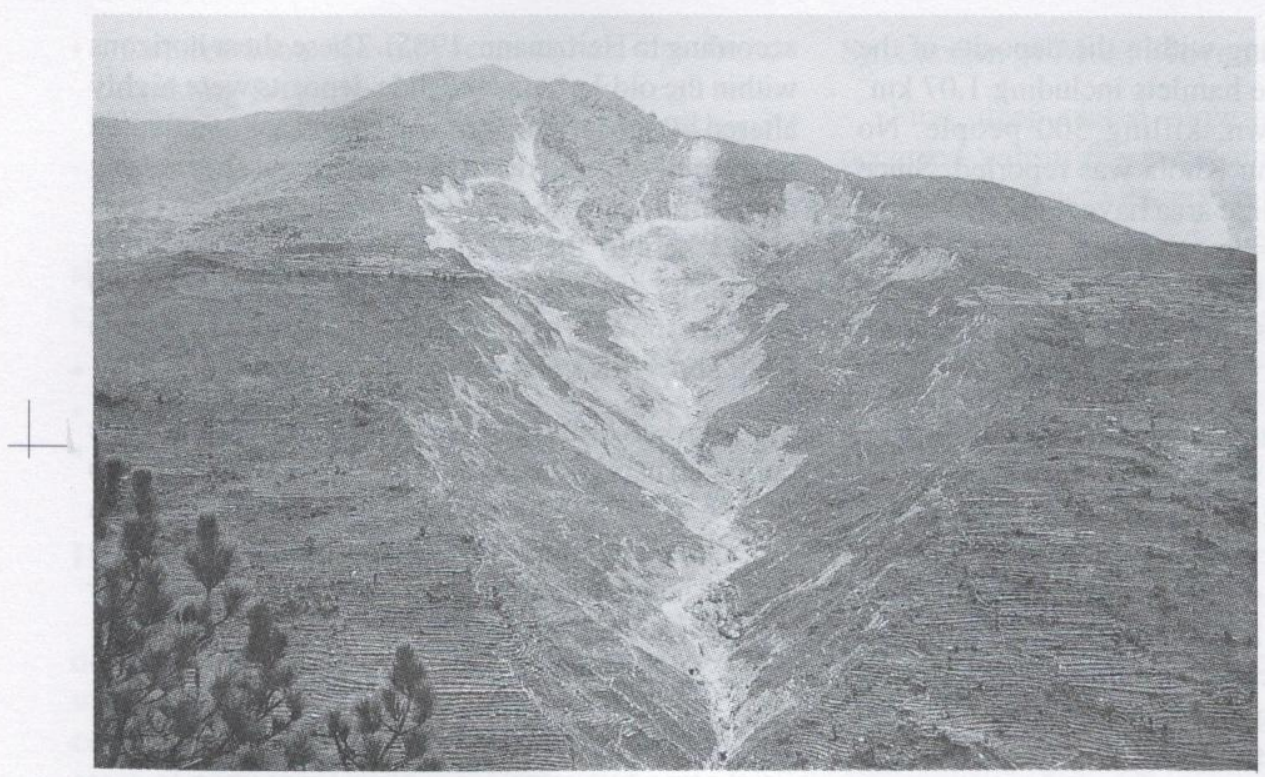

Fig.6: Idealized cross sections of wedge shaped slides within the Jarlang Gully.

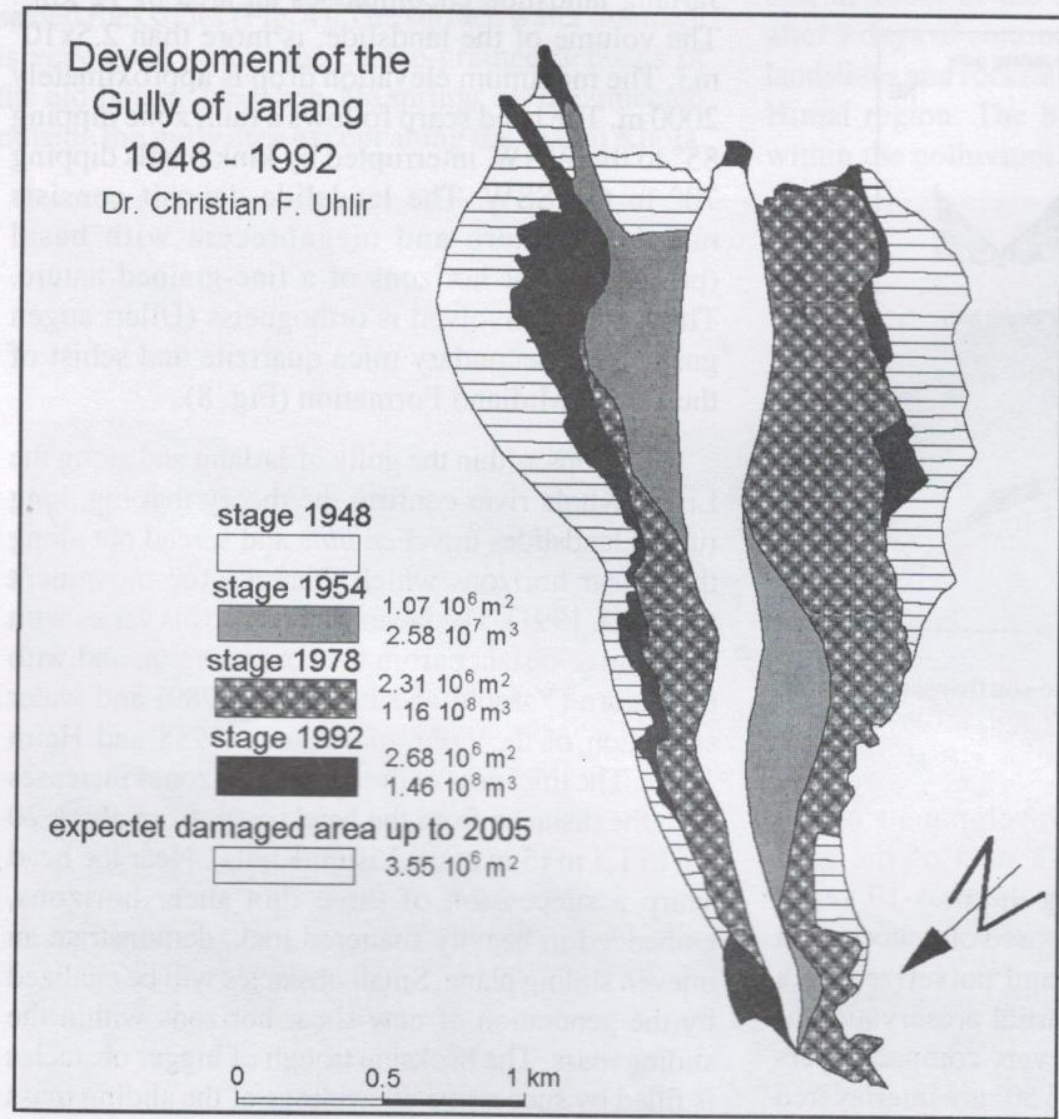

Figure 7: Sketch-map of development of the gully Jarlang (1948-1992). 


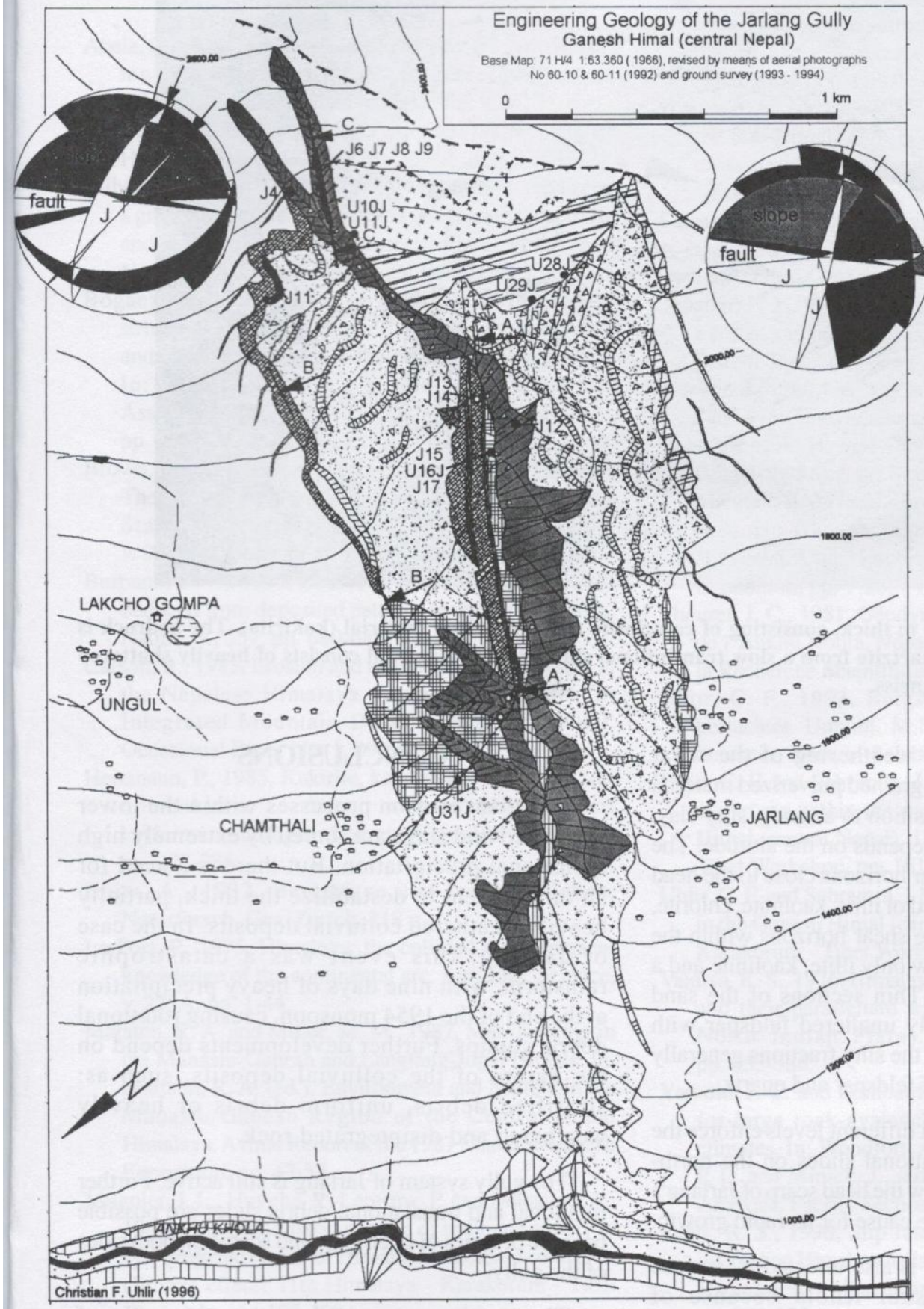

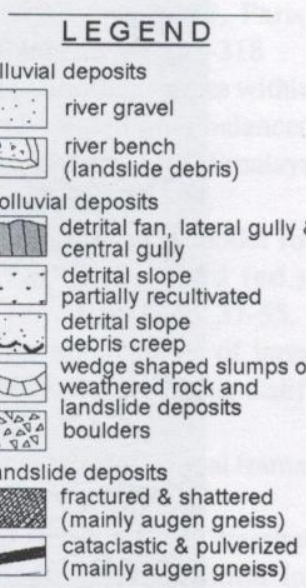

Lower Midland Formation

augen gneiss
compact - jointed
mica quartzite with
layers of quartzitic schists
compact - jointed
fractured
mica quartzite
compact
jointed

hydrology

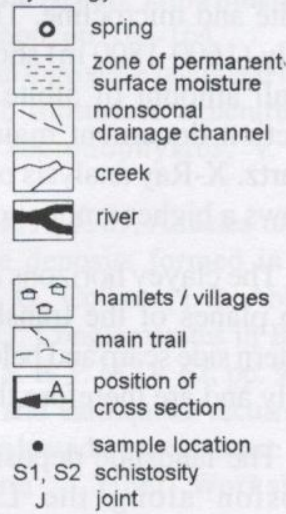

Fig. 8. Engineering geological map of the gully of Jarlang with cross-sections of the gully and the shear planes within the landslide deposit of Jarlang. Legend: $\mathrm{S}=$ shear horizon, $\mathrm{SE}=$ secondary shear horizons, $\mathrm{R}=$ rockslide, $\mathrm{QZ}=$ quartzite, $\mathrm{QZ}+\mathrm{S}=$ quartzite with mica schists, $\mathrm{G}=$ augen gneiss. 


\section{F. Uhlir and J.M. Schramm}

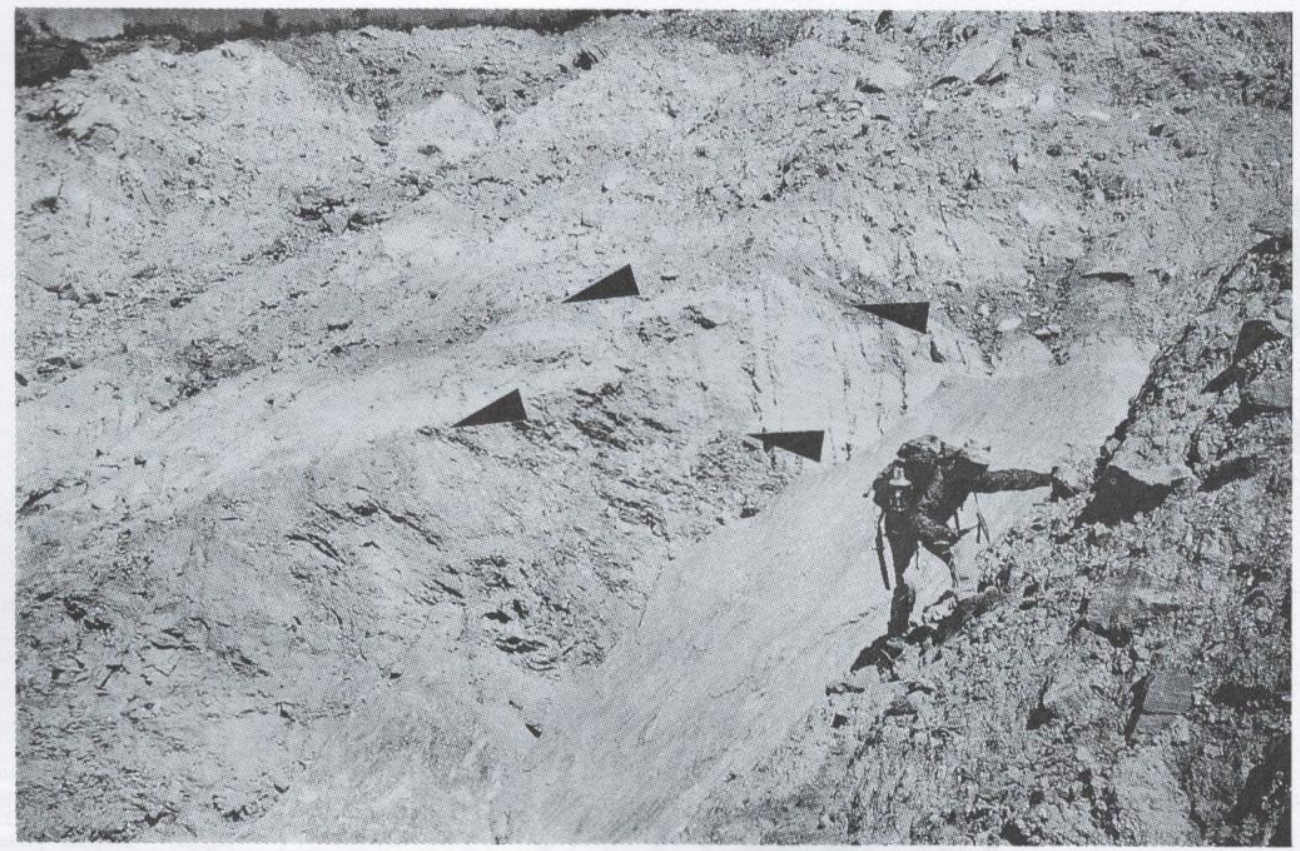

Fig. 9: Shear horizon, 1,5 m thick, consisting of cataclastic and pulverized material (kakirite). The bedrock is heavily shattered mica quartzite from a slow translational slide, the hanging wall consists of heavily shattered and disintegrated augen gneiss.

Subsurface physical weathering of the shear horizons changed the fine grained pulverized material with augen gneiss composition to a sandy, silty clay. The chemical alteration depends on the altitude. The clayey fraction of the shear horizons close to the head scarp (2400 m) is composed of illite, kaolinite, chlorite, albite and microcline. The shear horizons within the gully $(1600-1800 \mathrm{~m})$ show only illite, kaolinite and a small amount of albite. Thin sections of the sand fraction document mainly unaltered feldspar with quartz. X-Ray analysis of the silty fractions generally shows a higher amount of feldspar and quartz.

The clayey horizons at different levels enforce the slip planes of the translational slides on the northeastern side scarp and below the head scarp of Jarlang's gully and are therefore the cause for its rapid growth

The landslide deposit is also affected by surface erosion along the Lisuni Khola because of deforestation and slope undercutting. The relics of landslide deposits along the lower part of the Lisuni Khola show that the whole creek was filled with landslide debris and the Ankhu Khola was probably dammed at this site.

\section{CONCLUSIONS}

The giant erosion processes within the lower cultivated mid stage are forced by extremely high monsoonal precipitation. But there is a need for an initial event to destabilize the thick, partially heavily weathered colluvial deposits. In the case of Jarlang, this event was a catastrophic rainstorm, with nine days of heavy precipitation at the end of the 1954 monsoon, causing rotational debris slumps. Further developments depend on the nature of the colluvial deposits, such as: stratified debris, uniform debris or heavily weathered and disintegrated rock.

The gully system of Jarlang is still active. Further rotational and translational debris slides are possible because of series of open gaps and scarps on both sides of the gully.

The continuous growth within the gully of Jarlang will slow down the next years, as the bottom of the gully has already reached the parent rock. The activity may also be reduced by reforestation, recultivation and protection against grazing. 


\section{REFERENCES}

Abele, G., 1974, Bergstürze in den Alpen, ihre verbreitung, morphologie und folgeerscheinungen. Wissenschaftliche Alpenvereinshefte, v. 25, 230 p.

Amato, K. and Taira, A., 1992, Two-phase uplift of Higher Himalayas since 17 Ma. Geology, v. 20, pp. 391-394.

Bilham, R., Bodin, P. and Jackson, M., 1995, Entertaining a great earthquake in western Nepal: historic inactivity and geodetic test for the development of strain. Jour. Nepal Geol. Soc., v. 11(Special Issue), pp. 73-88.

Bogacz, W. and Krokowski, J., 1986, Mesoscopic structural studies of post-metamorphic deformations and tectonic evolution of the central Nepal Himalaya. In: Saklani, P.S. (ed.). Himalayan Thrust and Associated Rocks. Current Trends in Geology, v. 9, pp. 233-264.

Brown, W. M., Cruden, D. M. and Dennison, J. S., 1992, The directory of the world landslide inventory. United States Geological Survey, Open-File Report, v. 92(427), $216 \mathrm{p}$.

Burbank, D. W., 1992, Causes of recent Himalayan uplift deduced from deposited patterns in the Ganges basin. Nature, v., 357, pp. 680-683.

Carson, B., 1985, Erosion and sedimentation processes in the Nepalese Himalaya. International Centre for Integrated Mountain Development (ICIMOD), Occasional Paper No. 1, 39 p.

Heizmann, P., 1985, Kakirite, kataklasite, mylonite - zur nomenklatur der metamorphite mit verformungsgefügen. Eclogae Geol. Helv., v. 78(2), pp. 273-286.

Heim, A., 1932, Bergstürze und menschenleben. Naturforsch. Ges. Zürich, 218 p.

Le Fort, P., 1975, Himalaya: the collided range: present knowledge of the continental arc. Am. Jour. Science, v. $275 \mathrm{~A}$, pp. 1-44.

Marston, R. A. and Miller, M. M., 1987, Mass wasting in the Manaslu-Ganesh and Langtang-Jugal Himals. In: Martson, R. A. (ed.). Environment and Society in the Manaslu-Ganesh Region of the Central Nepal Himalaya. A final Report of the 1987 Manaslu-Ganesh Expedition, pp. 47-57.

Mugnier, J. L., Huyghe, P., Leturmy, P. and Delcailau, B., 1996, Plio-Quaternary increase of sediment supply in syn-orogenic basins of Himalayas: tectonic control or climatic effect? 11th Himalaya - Karakorum - Tibet Workshop, pp. 107-108.
Pecher, A., 1977, Geology of the Nepal Himalaya: deformation and petrography in the Main Central Thrust Zone. Colloque internationale 268, Paris, Ecologie et géologie de l'Himalaya, pp. 301-318

Powers, P. M. and Lille R. L., 1996, Shortening rate within the Sub-Himalaya of NW India based on a balanced cross-section of the Kangra Re-Entrant. 11th Himalaya - Karakorum - Tibet Workshop, pp. 107-108.

Sassa, K., 1988, Special lecture: geotechnical model for the motion of landslides. In: C. Bonnard (ed.). Landslides, Glissements de Terrain, v. 1, pp. 37-55.

Schaller, P. J., 1991, Analysis and implications of large martian and terrestrial landslides. Ph.D. thesis, Calif. Inst. of Tech., $604 \mathrm{p}$.

Stöcklin, J., 1980, Geology of Nepal and its regional frame. Jour. geol. Soc. London, v. 137, pp. 1-34

Thompson, A. H. and Devkota, L. P., 1989, Weather behaviour during the Manaslu-Ganesh Expedition. In: Marston, R. A. (ed.), Environment and Society in the Manaslu-Ganesh Region of the Central Nepal Himalaya. A final Report of the 1987 Manaslu-Ganesh Expedition, pp. 7-23.

Thouret, J. C., 1981, Géodynamique des grands versants de l'Ankhu Khola, Népal central. Centre National de la Recherche Scientifique (CNRS), 281 p.

Uhlir, C. F., 1993, Bergsturz Vigaun - geologisch betrachtet. Unpubl. M.Sc. thesis, Dept. of Natural Sciences, Univ. of Salzburg, Austria, $42 \mathrm{p}$.

Uhlir, C. F. and Schramm, J.-M., 1996a, The giant gully of Jarlang within the deposit of a landslide (Ganesh Himal, central Nepal). 11th Himalaya - Karakorum Tibet Workshop, pp. 161-162.

Uhlir, C. F. and Schramm, J.M., 1996b, Mass Movements in the Ganesh Himal (central Nepal). 11th Himalaya Karakorum - Tibet Workshop, pp. 163-164.

Valdiya, K. S., 1976, Himalayan transverse faults and folds and their parallelism with subsurface structures of North Indian Plains. Tectonophysics, v. 32, pp. 353-386.

Yarnold, J. C. and Lombard, J. P., 1989, A facies model for large rock-avalanche deposits formed in dry climates. In: Woodfort, A. O., Colburn, I. P., Abbott, P. L. and Minich, J., (eds.). Conglomerates in Basin Analysis, Pacific Section S. E. P. M., v. 62, pp. 9-3.

Yeats, R. S., 1996, Slip rate and earthquake recurrence interval on Himalayan plate boundary megathrust. 11 th Himalaya - Karakorum - Tibet Workshop, pp. 171-172. 